\title{
Plant composition and diversity at edges in a semi-natural forest-grassland mosaic
}

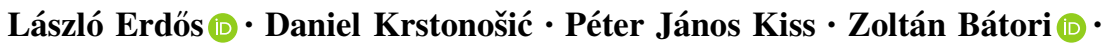 \\ Csaba Tölgyesi (i) $\cdot$ Željko Škvorc $(i)$
}

Received: 6 September 2018/ Accepted: 1 February 2019/Published online: 20 February 2019

(C) The Author(s) 2019

\begin{abstract}
As key components of landscapes, edges have received considerable scientific attention in anthropogenic ecosystems. However, edges in natural and semi-natural forest-grassland mosaics have received less attention, despite the fact that they cover a considerable proportion of these mosaic ecosystems. We studied forest edges in a semi-natural forestgrassland mosaic ecosystem of the Samobor Mountains (Croatia). Our aim was to compare the species composition, diversity and ecological indicator values
\end{abstract}

Communicated by Karen Harper.

Electronic supplementary material The online version of this article (https://doi.org/10.1007/s11258-019-00913-4) contains supplementary material, which is available to authorized users.

L. Erdős $(\bowtie)$

MTA Centre for Ecological Research, Institute of Ecology and Botany, VácrátótAlkotmány u. 2-4, 2163, Hungary

e-mail: erdos.laszlo@okologia.mta.hu

D. Krstonošić · Ž. Škvorc

Department of Forestry Genetics, Dendrology and

Botany, Faculty of Forestry, University of Zagreb,

Svetošimunska 25, 10000 Zagreb, Croatia

P. J. Kiss · Z. Bátori · C. Tölgyesi

Department of Ecology, University of Szeged,

SzegedKözép fasor 52, 6726, Hungary

P. J. Kiss

School of Environmental Sciences, University of Szeged,

SzegedRerrich Béla tér 1, 6720, Hungary of forest edges to those of the interior parts of the adjacent forest and grassland habitats. The vegetation was studied in 80 plots established in forest patch interiors, north-facing forest edges, south-facing forest edges and grassland interiors. We found that edges had a unique species composition, containing species from both the forest and the grassland interiors plus their own edge-related species (i.e. species that significantly preferred the edge habitat). These local edgerelated species did not correspond to regionallyidentified edge-related species. Compared to the forest and the grassland interiors, we revealed increased species richness in north-facing edges but not in southfacing edges. The mean light availability and nutrient supply indicator values of the edges were intermediate between those of the forest interiors and the grasslands. The mean soil moisture indicator values of the edges were similar to those of the grasslands. Our results show that edges form a unique component of forest-grassland mosaics, and they contribute considerably to landscape complexity, which should be taken into account during conservation decisions and habitat management.

Keywords Ecological boundary $\cdot$ Ecotone $\cdot$ Edge effect $\cdot$ Edge-related species $\cdot$ Forest edge $\cdot$ Habitat heterogeneity 


\section{Introduction}

Edges have received considerable attention in the ecological literature, as they are key structural and functional components of landscapes (Risser 1995; Cadenasso et al. 2003a; Ries et al. 2004, 2017; Yarrow and Marín 2007; Hufkens et al. 2009; Kolasa 2014). Edges influence the flow of organisms, materials and energy (Cadenasso et al. 2003b); influence population interactions (Fagan et al. 1999) and may serve as habitats or conduits for many species (Forman and Moore 1992).

Edges situated between forest and grassland ecosystems belong to the most conspicuous edge types (Forman and Moore 1992; Risser 1995; Cadenasso et al. 2003b). With accelerating forest fragmentation and an associated increase in edge proportion, forest edges have received considerable scientific attention in anthropogenic ecosystems (Merriam and Wegner 1992; Harper et al. 2005; Peters et al. 2006; Tokuoka et al. 2011; Dodonov et al. 2013; Haddad et al. 2015). For example, forest edges adjacent to clear-cuts (e.g. Chen et al. 1992; Euskirchen et al. 2001; Burton 2002; Harper and Macdonald 2002) or arable fields (e.g. Fraver 1994; Honnay et al. 2002; Devlaeminck et al. 2005) have been in the focus of ecological research. However, forest edges also play an important role in natural and semi-natural ecosystems, yet edges in these systems have received less attention in previous studies (but see Müller et al. 2012; Ibanez et al. 2013; Dislich and Mantovani 2016; Harper et al. 2018).

In Central and Southeast Europe, mosaic habitats consisting of alternating forest and grassland patches are an important component of landscapes, especially under relatively harsh conditions such as sand dunes and south-facing rocky slopes (Horvat et al. 1974; Öllerer 2014; Erdős et al. 2018a). A considerable proportion of these mosaic ecosystems, including extensively used pastures and pastures that have been abandoned recently, are semi-natural, i.e. modified by human activity but still dominated by native species that establish and reproduce spontaneously (Sjörs 1986).

Semi-natural landscapes in general and extensive pastures in particular have an outstanding conservation importance as they contain a large diversity of plants, including several rare species (Horvat et al. 1974; Ellenberg 1988; Bergmeier et al. 2010). It seems highly likely that the notable species diversity and natural value of forest-grassland mosaics are strongly connected to their high habitat heterogeneity, i.e. the presence of structurally very different patches in small proximity (e.g. Erdős et al. 2018b; Tölgyesi et al. 2018). Currently, however, the habitat heterogeneity of semi-natural forest-grassland mosaics is rapidly diminishing through different forms of homogenisation: overgrazing and intensification result in the disappearance of the forest component, while afforestation, the spread of invasive trees and the cessation of grazing threaten the survival of the grassland component (Bergmeier et al. 2010; Erdős et al. 2018b). It seems certain that a better understanding of the importance of habitat heterogeneity could contribute to a more efficient conservation of these valuable ecosystems.

Extensive and recently abandoned pastures typically have a fine-scale mosaic, that is, both the forest and the grassland patches are small (Horvat et al. 1974; Bergmeier et al. 2010; Erdős et al. 2011, 2018b; Borhidi et al. 2012). Consequently, the proportion of edge habitats is considerable, and they may have a disproportionately high conservation importance (Kent et al. 1997).

Edges have been proposed to have their own characteristic species composition, supporting species from both habitat interiors plus so-called edge-related species (i.e. species that tend to be concentrated within habitat edges) (Odum 1971; di Castri and Hansen 1992; Risser 1995; Kent et al. 1997). This has important conservation implications, as edge-related species, if they exist, would undoubtedly increase species richness at the landscape and regional scales (Naiman et al. 1988). Unfortunately, field studies are scarce, and the majority of them did not use any significance test to identify edge-related species (Lloyd et al. 2000; Baker et al. 2002).

Edges with different orientations tend to differ regarding environmental conditions (Chen et al. 1995; Gehlhausen et al. 2000; Ries et al. 2004; Heithecker and Halpern 2007), and consequently, regarding species composition (Dierschke 1974), which may contribute to a further increase in landscape- or regional-scale diversity. However, these differences remain poorly understood in semi-natural forestgrassland mosaics.

From a nature conservation perspective, edges may also be extremely important components of 
landscapes because their habitat-scale diversity is sometimes expected to be greater than that of either of the two adjacent habitat interiors (Odum 1971; Pianka 1983; Risser 1995; Kent et al. 1997). However, Ries et al. (2017) pointed out that this should not be considered a general phenomenon. Van der Maarel (1990) suggested that only blurred edges with stable environmental conditions have higher diversity than patch interiors, while abrupt edges with fluctuating environmental conditions (i.e. strong microclimatic variations in time) have lower diversity. Some field evidence shows that edge diversity may be intermediate between the diversities of the two habitat interiors (Walker et al. 2003; Erdős et al. 2011). The results of Łuczaj and Sadowska (1997) emphasise that edge diversity may vary considerably among different taxonomic groups. So far, generalisations have been rather difficult because of the limited number of case studies, especially for semi-natural systems (Harper et al. 2005; Kark and van Rensburg 2006).

In spite of the important role edges presumably play in these complex semi-natural mosaic ecosystems, their properties have been addressed by a surprisingly low number of studies. Our aim was to investigate forest edges in a semi-natural mosaic ecosystem with no current management activity, where small forest patches are embedded in a grassland matrix. We studied north- and south-facing forest edges in relation to the neighbouring forest and grassland habitats. Our specific questions were as follows: (1) Do edges have a specific species composition that differs from the habitat interiors? (2) Do edges possess their own edgerelated species that significantly prefer edge habitats? (3) Do edges have larger per plot species richness and Shannon diversity than forest and grassland interiors? (4) Is the proportion of phytosociological preference groups different between habitat interiors and edges? (5) Are the mean ecological indicator values of edges and habitat interiors different? (6) Are north-facing and south-facing edges different regarding the above characteristics?

\section{Materials and methods}

Study area

Our study was conducted in the Samobor Mountains (northwest Croatia), which form a transition between the Alps, the Dinarides and the Carpathian Basin (Trinajstić 1995). We chose a south-facing slope (N45 $48^{\prime} 02^{\prime \prime}, \mathrm{E} 15^{\circ} 38^{\prime} 30^{\prime \prime}$ ) west of the town of Samobor. The elevation is $370-410 \mathrm{~m}$ asl, the bedrock is dolomite and the soil is rendzina (Mayer and Vrbek 1995; Trinajstić 1995). The mean annual temperature in Samobor is $11^{\circ} \mathrm{C}$, and the mean annual precipitation is $1015 \mathrm{~mm}$, most of which falls in June and October-November (Mayer and Vrbek 1995). The natural vegetation of the study site consists of xeric forests. As a result of human impact (grazing and mowing), these forests have developed into a mosaic of xeric forest patches and dry grasslands (Horvat et al. 1974) (Fig. 1). The size of the forest patches usually varies between ca. 0.02 and 0.2 ha. Due to the high number of protected and rare species, these mosaics have extreme conservation importance but are diminishing as pastures and meadows are abandoned.

The forest component of the vegetation mosaic in the study site is represented by the calcareous pubescent oak - hophornbeam forest Querco-Ostryetum carpinifoliae. This is a thermophilous community distributed in the western Balkan Peninsula, preferring the south-facing slopes of mountains and hills (Horvat et al. 1974). The canopy layer has a cover of $60-80 \%$ and is co-dominated by flower ash (Fraxinus ornus), hophornbeam (Ostrya carpinifolia) and pubescent oak (Quercus pubescens). The shrub layer cover varies between 10 and $50 \%$ and is primarily composed of common dogwood (Cornus sanguinea), common buckthorn (Rhamnus cathartica) and wayfarer (Viburnum lantana). The most common species in the herb layer include branched St Bernard's-lily (Anthericum ramosum), upright brome (Bromus erectus), blue sedge (Carex flacca), winter heath (Erica herbacea) and angular Solomon's seal (Polygonatum odoratum). The grassland component is formed by the upright brome-hoary plantain grassland community Bromo erecto-Plantaginetum mediae, a meso-xerophytic basiphilous grassland of the western Balkans (Horvat et al. 1974). The dominant species are branched St Bernard's-lily (A. ramosum), upright brome (Bromus erectus), winter heath (E. herbacea), cypress spurge (Euphorbia cyparissias), hog's fennel (Peucedanum oreoselinum), wall germander (Teucrium chamaedrys) and broad-leaved thyme (Thymus pulegioides).

The study site was used as an extensively managed pasture, but grazing stopped in the 1980s. Currently there is no land-use or management activity. 


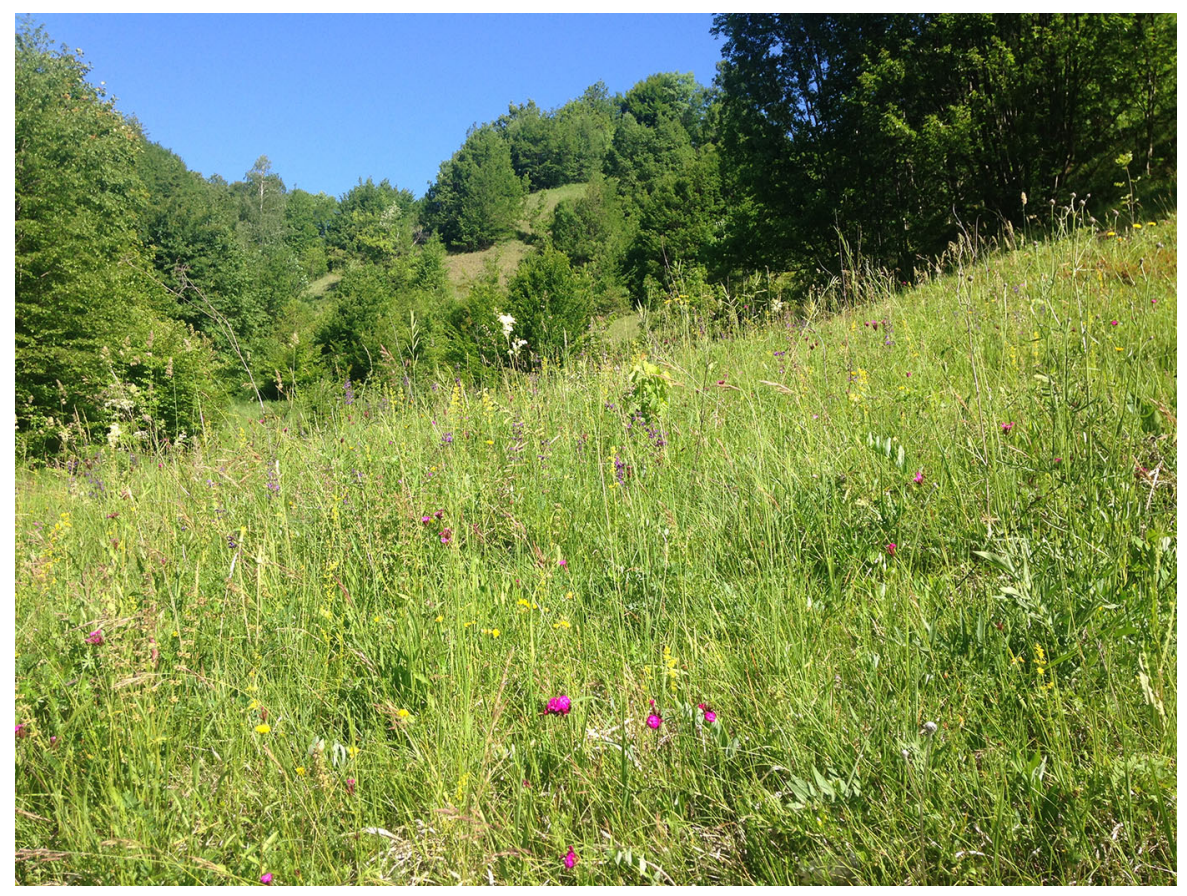

Fig. 1 The forest-edge-grassland complex at the study site in the Samobor Mountains

Species names are used according to The Plant List (www.theplantlist.org), and plant community names follow the nomenclature of Trinajstić (2008).

Field work

Twenty forest patches were selected for the study. For all patches, four $2 \mathrm{~m} \times 1 \mathrm{~m}$ plots were established in the following arrangement, corresponding to four different habitats: one plot in the forest patch interior, one plot in the north-facing forest edge, one plot in the south-facing forest edge and one plot in the neighbouring grassland. We thus used a total of 80 plots $(20$ patches $\times 4$ habitats). The minimum distance between neighbouring patches was $75 \mathrm{~m}$, while the distance between the neighbouring plots in the four habitats belonging to the same patch was $10-15 \mathrm{~m}$. An edge was defined as the zone outside of the outermost tree trunks but still under the canopy. Forest edges in similar ecosystems are usually very narrow (Jakucs 1972; Erdős et al. 2011, 2014); thus, using small and elongated plots ensured that the plots fit into the edges. The cover of all vascular plant species of all vegetation layers was visually estimated in May 2017. As the canopy layer was low (typically 4-5 m, sometimes even less), and it merged with the shrub layer, the shrub and the canopy layers were treated jointly in this work.

\section{Data analysis}

To study the compositional differences among the four habitats, detrended correspondence analysis (DCA) (Hill and Gauch 1980) was performed on square roottransformed cover scores. The analysis was carried out in the $\mathrm{R}$ environment ( $\mathrm{R}$ Core Team 2018) using the 'decorana' function of the vegan package (Oksanen et al. 2018).

We prepared a Venn diagram to show the number of species that are restricted to a single habitat and the number of species that are present in two or more habitats. We used the online Venn diagram generator of the Bioinformatics and Systems Biology Group of the Department of Plant Systems Biology, Ghent University (https://bioinformatics.psb.ugent.be/ webtools/Venn/).

We also statistically identified diagnostic species, i.e. species that preferentially occur in certain habitats and are absent or rare in the other habitats (Barkman 1989). For this purpose, we used the phi coefficient, which has been shown to be an appropriate indicator of species' concentrations in certain habitats (Chytrý 
et al. 2002; Tichý and Chytrý 2006). The phi coefficient compares the observed frequencies of a species within a given community with frequencies that would be expected if the species was randomly distributed. The coefficient varies between -1 and + 1; higher values reflect higher diagnostic values. Significant diagnostic species were identified with Fisher's exact test. We used JUICE 7.0.45 software (Tichý 2002) for the calculations.

Species number and Shannon diversity were computed for each plot. To examine whether there were any significant differences between the habitats, we applied the Friedman test using the 'friedman.test' function of the stats package (R Core Team 2018). The individual patches were used as blocking factor in the analyses. For the post-hoc pairwise comparisons of the habitats, the Nemenyi test was used with the 'posthoc.friedman.nemenyi.test' function of the PMCMRv4.3 package (Pohlert 2014).

All species were classified into phytosociological preference groups according to Borhidi (1995) and the Flora Croatica Database (https://hirc.botanic.hr/fcd/). Frequency distributions were calculated for each habitat, which were then compared using Pearson's chi-square test with the 'chisq.test' function of the stats package (R Core Team 2018). For the post-hoc pairwise comparisons of the frequency distributions of the habitats, we used the 'pairwiseNominalIndependence' function of the rcompanion package (Mangiafico 2018).

We also calculated the mean ecological indicator values for soil moisture, light availability and nutrient supply for each plot. We used the indicator values of Pignatti (2005), which are based on the values of Ellenberg et al. (1992) but extended for southern Europe. Earlier field measurements have shown that ecological indicator values are able to provide reliable estimates of site conditions (e.g. Schaffers and Sýkora 2000; Dzwonko 2001; Tölgyesi et al. 2014). It has been shown that mean ecological indicator values perform well and have a solid theoretical basis (ter Braak and Gremmen 1987; Diekmann 2003). The Friedman test was used to examine differences among the habitats, using the 'friedman.test' function of the stats package (R Core Team 2018), while the Nemenyi test was used for post-hoc comparisons, using the 'posthoc.friedman.nemenyi.test' function of the PMCMRv4.3 package (Pohlert 2014).

\section{Results}

We found a total of 131 plant species in the 80 plots (species cover values for all plots can be found in the Online Resource 1). North-facing edges had 93 species, south-facing edges had 88 species, while 88 species occurred in the forests, and 61 species in the grasslands.

According to the DCA ordination, forest plots and grassland plots formed two well-distinguishable groups (Fig. 2). Edge plots were situated in an intermediate position. North-facing edges and southfacing edges overlapped considerably in the ordination space.

A large number of species occurred in all four studied habitats (39 species) (Fig. 3). Somewhat fewer species were shared among forests, north-facing edges and south-facing edges (16 species) or between forests and north-facing edges (10 species). The number of species restricted to north-facing edges (14 species) or forests (12 species) was also considerable.

Forests had 16 diagnostic species, while grasslands had 11 diagnostic species (Table 1). The number of diagnostic species in north-facing and south-facing edges was 10 and 5, respectively. Notably, the diagnostic species of edges had rather low fidelity values. Among the significant diagnostic species of north-facing edges, there was only one species (Peucedanum cervaria) that is regionally regarded as edge-related. The situation was similar for southfacing edges, since Peucedanum oreoselinum was the only diagnostic species known for its regional affinity to edges. However, in our study, this species was also diagnostic for grasslands.

Habitat type had a significant influence on per plot species number according to the Friedman test $\left(\chi^{2}=13.338\right.$, df $\left.=3, p<0.01\right)$. As shown by the post-hoc tests, north-facing edges were the most species rich, while forests and grasslands had significantly lower per plot species numbers (Fig. 4a). South-facing edges did not differ significantly from any other habitat, although they seemed to be more species rich than habitat interiors.

Habitat type significantly influenced Shannon diversity, as indicated by the Friedman test $\left(\chi^{2}=14.460\right.$, df $\left.=3, p<0.01\right)$. The post-hoc comparisons showed that forests had the lowest Shannon diversity values, north-facing edges and grasslands 


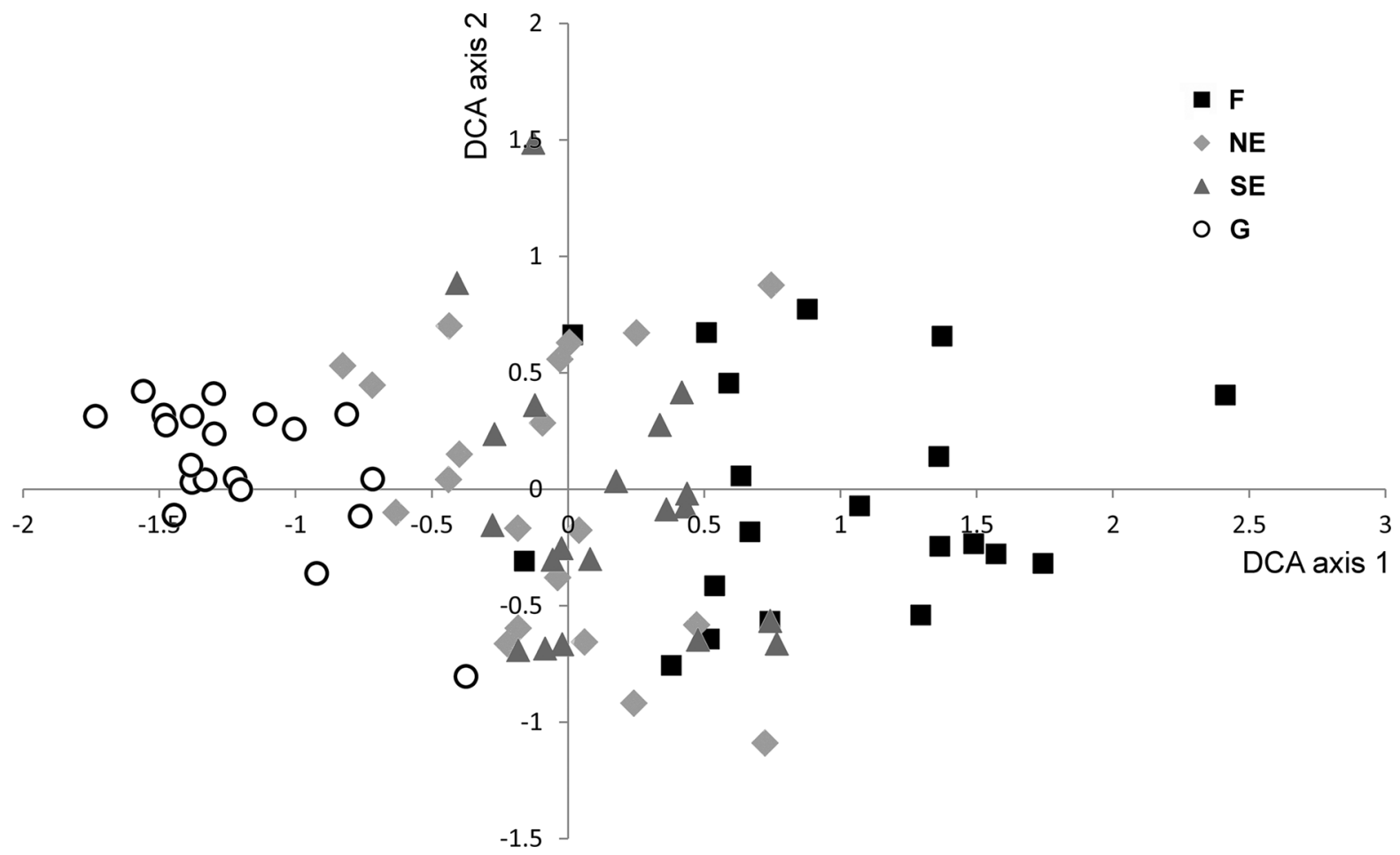

Fig. 2 DCA ordination scattergram of the 80 plots. $F$ forest, $N E$ north-facing edge, $S E$ south-facing edge, $G$ grassland. Eigenvalues of the first and second axes were 0.503 and 0.418 , respectively

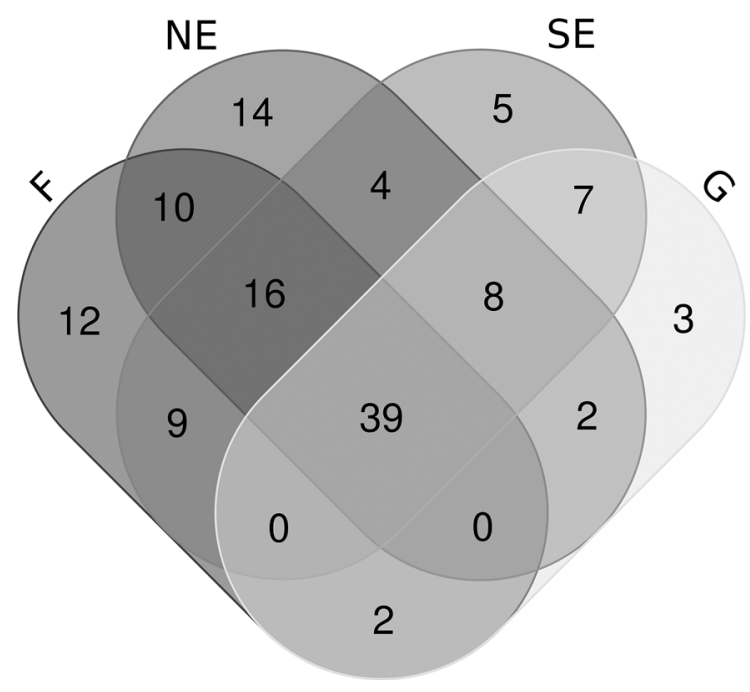

Fig. 3 Venn diagram of all species found in the study plots, according to their habitats. $F$ forest, $N E$ north-facing edge, $S E$ south-facing edge, $G$ grassland

were significantly more diverse, while south-facing edges were intermediate (Fig. 4b).
There were significant differences among the frequency distributions of the phytosociological preference groups in the four habitat types, as shown by Pearson's chi-square test $\left(\chi^{2}=209.43\right.$, df $=18$, $p<0.001)$. The post-hoc tests revealed no significant differences between north-facing edges and southfacing edges, while the other habitats differed significantly from one another (Fig. 5). The forest habitat was dominated by species of mesic and xeric forests and scrubs, while species of mesic and xeric grasslands were more typical than other types of species in the grassland habitat. Edges were generally intermediate: the proportion of species of mesic and xeric forests and scrubs was lower than in the forest interior but higher than in the grassland interior, while the reverse pattern was true for the species of mesic and xeric grasslands.

Mean ecological indicator values differed significantly among the four habitats, as shown by the Friedman test (soil moisture: $\chi^{2}=33.603$, df $=3$, $p<0.001$, light availability: $\chi^{2}=48.780$, df $=3$, $p<0.001$, nutrient supply: $\chi^{2}=39.780$, df $=3$, $p<0.001)$. According to the post-hoc tests, forests 
Table 1 Diagnostic species of the four studied habitats with fidelity values and regional phytosociological preferences

\begin{tabular}{|c|c|c|c|c|c|}
\hline & $F$ & $\mathrm{NE}$ & SE & G & Phytosociological preference \\
\hline Lonicera caprifolium & $0.524 * * *$ & & & & $M+X$ forest \\
\hline Hedera helix & $0.522 * * *$ & & & & $M+X$ forest \\
\hline Cornus sanguinea & $0.443 * * *$ & & & & Indiff \\
\hline Dioscorea communis & $0.418 * * *$ & & & & $M+X$ forest \\
\hline Primula vulgaris & $0.393 * *$ & & & & M forest \\
\hline Mercurialis ovata & $0.384 * *$ & & & & $\mathrm{X}$ forest \\
\hline Campanula persicifolia & $0.343 * *$ & & & & $M+X$ forest \\
\hline Sorbus aria & $0.342 * *$ & & & & Indiff \\
\hline Cephalanthera damasonium & $0.328 *$ & & & & $M+X$ forest \\
\hline Viburnum lantana & $0.328 *$ & & & & $\mathrm{X}$ forest \\
\hline Ligustrum vulgare & $0.293^{*}$ & & & & $M+X$ forest \\
\hline Rosa canina & $0.274 *$ & & & & Scrub \\
\hline Quercus cerris & $0.265^{*}$ & & & & $\mathrm{X}$ forest \\
\hline Fraxinus ornus & $0.254^{*}$ & $0.254 *$ & & & $\mathrm{X}$ forest \\
\hline Viola hirta & $0.246^{*}$ & & & & Edge \\
\hline Quercus pubescens & $0.229 *$ & $0.229 *$ & $0.300 * *$ & & $\mathrm{X}$ forest \\
\hline Koeleria pyramidata & & $0.303 * *$ & & $0.303 * *$ & $\mathrm{X}$ forest \\
\hline Hypochaeris maculate & & $0.274 *$ & & & $\mathrm{X}$ grassland \\
\hline Leontodon incanus & & $0.272 *$ & & & $\mathrm{X}$ grassland \\
\hline Lotus corniculatus & & $0.265^{*}$ & & & Indiff \\
\hline Peucedanum cervaria & & $0.265^{*}$ & & & Edge \\
\hline Brachypodium pinnatum & & $0.242 *$ & & & $\mathrm{X}$ grassland \\
\hline Ostrya carpinifolia & & $0.231 *$ & & & $\mathrm{X}$ forest \\
\hline Carex flacca & & $0.222 *$ & & & Indiff \\
\hline Euphorbia cyparissias & & & $0.322 * *$ & $0.322 * *$ & Indiff \\
\hline Hypericum perforatum & & & $0.265^{*}$ & & Indiff \\
\hline Prunus avium & & & $0.251 *$ & & $M$ forest \\
\hline Peисеdanum oreoselinum & & & $0.217 *$ & $0.217^{*}$ & Edge \\
\hline Globularia punctata & & & & $0.613 * * *$ & $\mathrm{X}$ grassland \\
\hline Anthyllis vulneraria & & & & $0.449 * * *$ & $\mathrm{X}$ grassland \\
\hline Thymus pulegioides & & & & $0.435 * * *$ & $\mathbf{M}$ grassland \\
\hline Helianthemum nuтmularium & & & & $0.419 * * *$ & $\mathrm{X}$ grassland \\
\hline Bromus erectus & & & & $0.412 * * *$ & $\mathrm{X}$ grassland \\
\hline Scabiosa columbaria & & & & $0.311 * *$ & $\mathrm{X}$ grassland \\
\hline Carex caryophyllea & & & & $0.295 * *$ & Indiff \\
\hline Silene vulgaris & & & & $0.291 *$ & Indiff \\
\hline
\end{tabular}

$F$ forest, $N E$ north-facing edge, $S E$ south-facing edge, $G$ grassland, edge species of edges, $M$ forest species of mesic forests, $M$ grassland species of mesic grasslands, $M+X$ forest species of mesic and xeric forests, indiff species occurring in woody and nonwoody habitats, scrub species of scrubs, $X$ forest species of xeric forests, $X$ grassland species of xeric grasslands

$* p<0.05, * * p<0.01, * * * p<0.001$

had significantly higher moisture values than the other three habitats (Fig. 6a). Forests had the lowest and grassland the highest light indicator values, while edges were intermediate (Fig. 6b). Forests proved to have the highest nutrient values, while grasslands were nutrient-poor, edges being intermediate (Fig. 6c). 
(a)

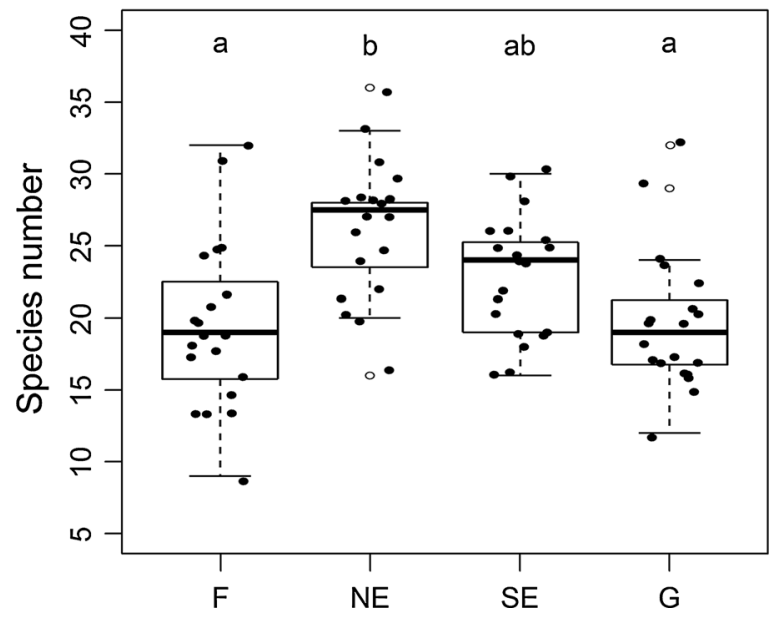

(b)

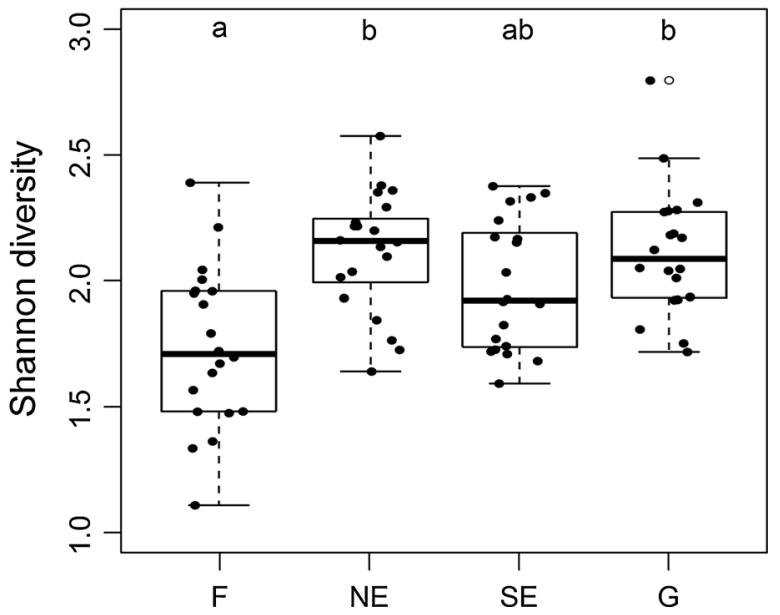

Fig. 4 Species number (a) and Shannon diversity (b) of the four studied habitats. Boxes not sharing a letter are significantly different. $F$ forest, $N E$ north-facing edge, $S E$ south-facing edge, $G$ grassland

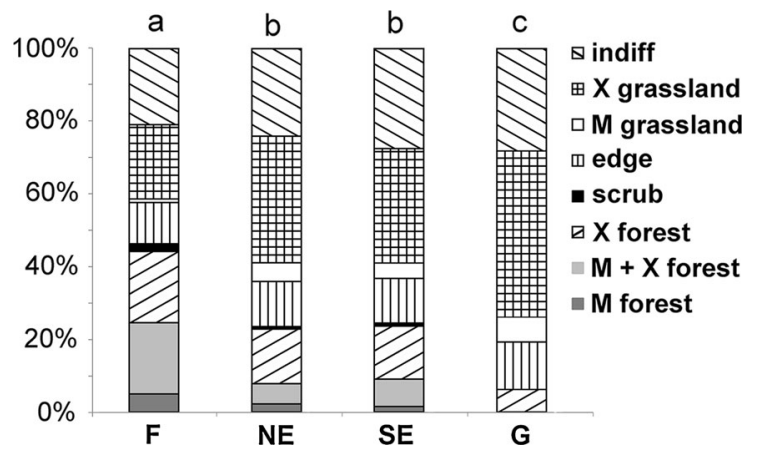

Fig. 5 Frequency distributions of phytosociological preference categories in the four studied habitats. Habitats not sharing a letter are significantly different. $F$ forest, $N E$ north-facing edge, $S E$ south-facing edge, $G$ grassland. Indiff species occurring in woody and non-woody habitats, $X$ grassland species of xeric grasslands, $M$ grassland species of mesic grasslands, edge species of edges, scrub species of scrubs, $X$ forest species of xeric forests, $M+X$ forest species of mesic and xeric forests, $M$ forest species of mesic forests

\section{Discussion}

Our analyses showed that edges have a plant species composition that clearly differs from that of both the forest and grassland habitats, although overlaps do exist. Similar results for specific edge compositions were reported from other xeric forest-grassland mosaics such as the sandy forest-steppes of the Carpathian Basin (Erdős et al. 2013, 2014), Argentina's semi-arid Chaco forests (de Casenave et al. 1995), savannas in southern Brazil (Müller et al. 2012), African semi-natural savanna landscapes (Hennenberg et al. 2005) and Kazakh forest-steppes (Bátori et al. 2018). Thus, based on species composition, it seems justifiable to treat edges as separate communities in all the abovementioned study areas. However, different patterns also exist. For example, the species composition of edges may be very similar to that of forest interiors, as was the case in the xeric scrub of the Brazilian Caatinga (Santos and Santos 2008). Alternatively, edge composition may be similar to the composition of grassland interiors, as was shown by Erdös et al. (2011) in a xeric rocky scrubland in the Carpathian Basin.

Edges in our study area hosted both forest-related and grassland-related species. This result, however, was also obtained for the forest and grassland habitats (i.e. grassland-related species occurred in the forests, and some forest-related species were found in the grasslands). This fact may be explained by the finescale mosaic pattern of the study area (Horvat et al. 1974; Vukelić 2012): forest patches are so small that their total area is affected by the neighbouring grasslands; because the forest patches have a relatively dry and warm microclimate, colonisation by grassland species can occur. Similarly, the small grassland patches are probably influenced by the canopy of the nearby trees, and therefore, some forest species can easily extend into grasslands (Baker et al. 2013). 

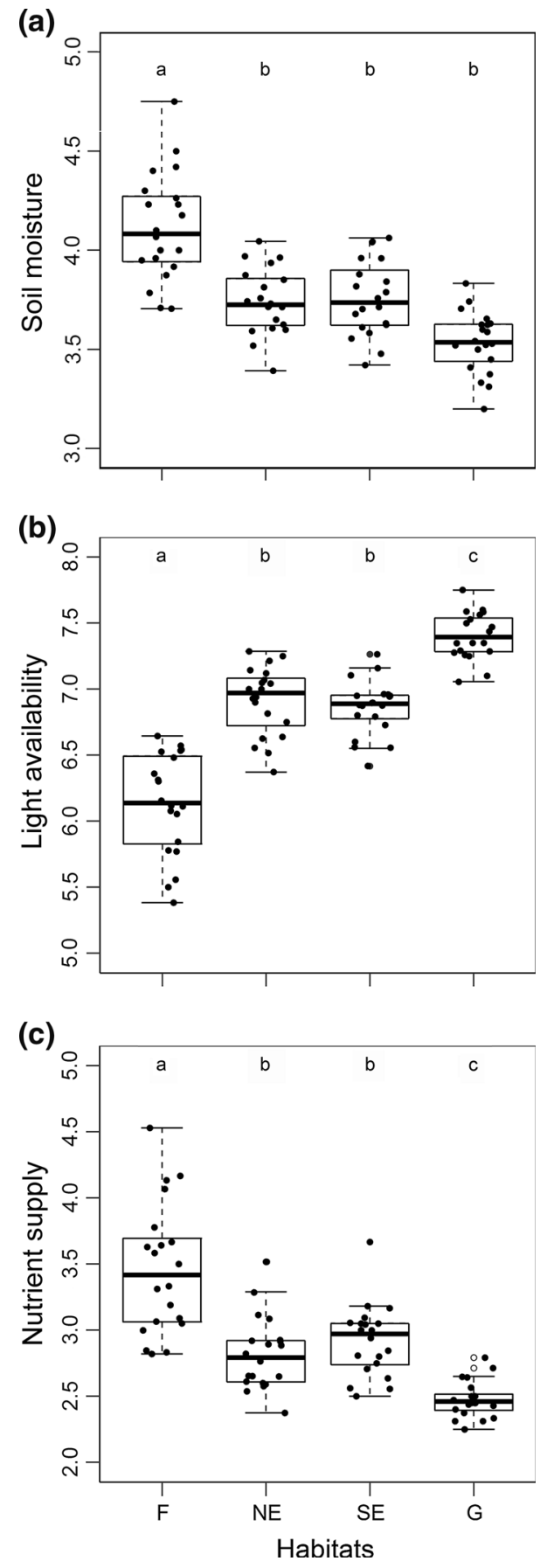

Fig. 6 Mean ecological indicator values of the four habitats for soil moisture (a), light availability (b) and nutrient supply (c). $F$ forest, $N E$ north-facing edge, $S E$ south-facing edge, $G$ grassland

As predicted by the edge effect theory (e.g. Risser 1995; Kent et al. 1997), edges had their own species, i.e. species that were significantly concentrated in edges. Interestingly, species that are regarded as edge related in regional phytosociological databases were under-represented among the significant edge diagnostic species identified in our study area. This result indicates that local edge species do not necessarily correspond to regional edge species (Lloyd et al. 2000; Erdös et al. 2013). Some species that are common outside of edges in a given region may be restricted to edges locally, provided that only edges have an appropriate combination of environmental factors in that specific location.

Per plot species richness was highest in northfacing edges, followed by south-facing edges; however, south-facing edges were not significantly different from the forest and grassland habitats. The Shannon diversity of north-facing edges was higher than that of forests but did not differ significantly from that of grasslands, while the diversity of south-facing edges did not differ significantly from any of the other studied habitats. Increased species richness has also been found in similar xeric forest-grassland mosaics in Eastern Europe (Molnár 1998; Erdős et al. 2013, 2014), Asia (Bátori et al. 2018) and South America (de Casenave et al. 1995).

The total (i.e. pooled) species number was highest in north-facing edges and slightly lower in southfacing edges and forests, while it was lowest in grasslands (Fig. 7). In an earlier study conducted in the Carpathian Basin, Erdös et al. (2013) also found that the total species number was highest in the edge habitat. However, grasslands in that study were almost as species rich as edges, while forests were particularly species poor, which is in contrast to the species richness patterns of the Samobor Mountains revealed in our present study. One possible explanation for these differences may be found in biogeographic patterns. The Samobor Mountains belong to the zone of deciduous forests, where grasslands were formed by human activity in historical times (Ellenberg 1988). This pattern explains why the species pool of forests exceeds that of grasslands. In contrast, substantial parts of the Carpathian Basin belong to the foreststeppe belt (Magyari et al. 2010), where grasslands are natural and have a much longer history, resulting in a considerably larger species pool.

According to the ecological indicator values, edges had mostly intermediate environmental conditions between the forest and the grassland habitats (Fig. 7), which is in line with earlier studies based on direct 
(a)

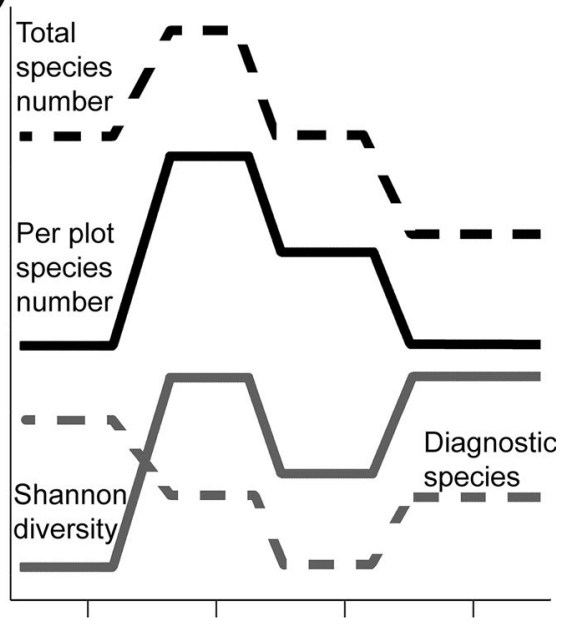

(b)

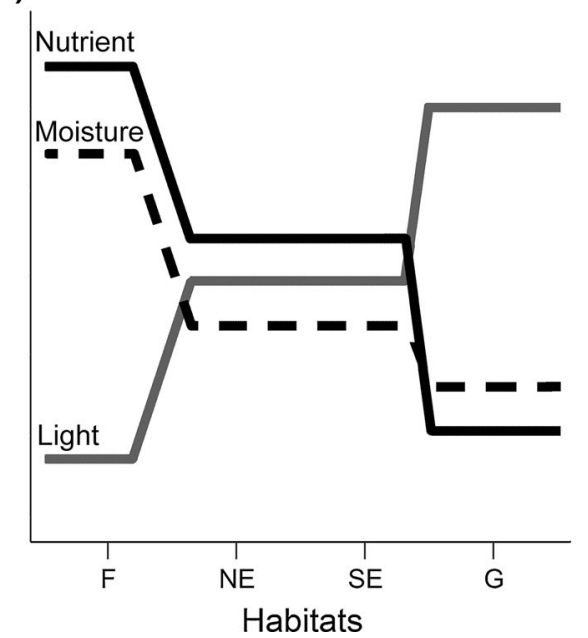

Fig. 7 Schematic representation of the main results of the study for $\mathbf{a}$ species number and diversity and $\mathbf{b}$ ecological indicator values. St total species number, $S p$ per plot species number, $D$ number of diagnostic species, $H$ Shannon diversity, $M$ soil moisture indicator values, $L$ light availability indicator values, $N$ nutrient supply indicator values, $F$ forest, $N E$ north-facing edge, $S E$ south-facing edge, $G$ grassland

measurements (e.g. Cadenasso et al. 1997; Heithecker and Halpern 2007; Erdős et al. 2014) or ecological indication (e.g. Erdős et al. 2013; Palo et al. 2013).

We found moderate differences between northfacing and south-facing edges regarding species composition, while no significant differences were revealed regarding species richness, Shannon diversity, phytosociological preference groups and mean ecological indicator values. Some earlier studies suggested that there may be considerable differences between differently exposed edges in terms of abiotic factors (Ries et al. 2004; Wicklein et al. 2012), species richness (Fraver 1994; Erdős et al. 2013, 2018a, 2018b) and species composition (Brothers and Spingarn 1992; Fraver 1994). However, the study of Erdös et al. (2011), conducted in a recently abandoned pasture with a fine-scale forest-grassland mosaic found no significant differences between differently exposed slopes, which is in line with our current results.

In sum, we found that edges have a unique species composition, supporting species from both habitat interiors plus their own edge-related species. These edge-related species did not correspond to regionallyidentified edge-related species. We found evidence for increased species richness in north-facing edges (Fig. 7), while this was not true for south-facing edges. Our findings support the notion that edges should be recognised as a special component of forestgrassland mosaics, which has important conservation implications. In many forest-grassland mosaics of Europe, land abandonment results in succession and gradual development into forest or shrubland (Ellenberg 1988). This process is considered undesirable, as grasslands represent high conservation value (Dengler et al. 2014; Valkó et al. 2018). It is clear, however, that if the mosaic character is lost with ongoing succession, not only the grassland but also the edge component will disappear. As shown by our results, edges contribute considerably to the compositional and structural complexity of the landscape. Thus, forestgrassland mosaics should be preserved not only because of grasslands but also because of edges.

The re-establishment of traditional low-intensity, extensive agricultural practises has been suggested as an appropriate management tool to preserve seminatural grasslands in many European landscapes (Ostermann 1998). The historical land-use of our study area in the Samobor Mts is grazing. It has been shown that in such cases grazing is the best option, as many species are adapted to the specific disturbance dynamics of grazing (Römermann et al. 2009). Unfortunately, grazing may not be an economically viable solution any more. While mowing and mulching may be less favourable from a nature conservation perspective, they are usually considered acceptable alternatives in calcareous grasslands, as they are easier to implement and are able to maintain the mosaic 
character of the habitat (Kahmen et al. 2002; Moog et al. 2002; Wallis de Vries et al. 2002).

Acknowledgements Open access funding provided by MTA Centre for Ecological Research (MTA ÖK). This work was supported by a Croatia-Hungary bilateral scholarship. The contribution of Zoltán Bátori was supported by the National Research, Development and Innovation Office (Grant No. K 124796).

\section{Compliance with ethical standards}

Conflict of interest The authors declare that they have no conflict of interest.

Open Access This article is distributed under the terms of the Creative Commons Attribution 4.0 International License (http:// creativecommons.org/licenses/by/4.0/), which permits unrestricted use, distribution, and reproduction in any medium, provided you give appropriate credit to the original author(s) and the source, provide a link to the Creative Commons license, and indicate if changes were made.

\section{References}

Baker J, French K, Whelan RJ (2002) The edge effect and ecotonal species: bird communities across a natural edge in southeastern Australia. Ecology 83:3048-3059. https://doi. org/10.1890/0012-9658(2002)083[3048:TEEAES]2.0. $\mathrm{CO} ; 2$

Baker SC, Spies TA, Wardlaw TJ, Balmer J, Franklin JF, Jordan GJ (2013) The harvested side of edges: Effect of retained forests on the re-establishment of biodiversity in adjacent harvested areas. Forest Ecol Manag 302:107-121. https:// doi.org/10.1016/j.foreco.2013.03.024

Barkman JJ (1989) Fidelity and character-species, a critical evaluation. Vegetatio 85:105-116. https://doi.org/10.1007/ BF00042260

Bátori Z, Erdős L, Kelemen A, Deák B, Valkó O, Gallé R, Bragina TM, Kiss PJ, Gy Kröel-Dulay, Cs Tölgyesi (2018) Diversity patterns in sandy forest-steppes: a comparative study from the western and central Palaearctic. Biodivers Conserv 27:1011-1030. https://doi.org/10.1007/s10531017-1477-7

Bergmeier E, Petermann J, Schröder E (2010) Geobotanical survey of wood-pasture habitats in Europe: diversity, threats and conservation. Biodivers Conserv 11:2995-3014. https://doi.org/10.1007/s10531-010-98723

Borhidi A (1995) Social behaviour types, the naturalness and relative ecological indicator values of the higher plants in the Hungarian Flora. Acta Bot Hung 39:97-181

Borhidi A, Kevey B, Lendvai G (2012) Plant communities of hungary. Academic Press, Budapest

Brothers TS, Spingarn A (1992) Forest fragmentation and alien plant invasion of Central Indiana old-growth forests.
Conserv Biol 6:91-100. https://doi.org/10.1046/j.15231739.1992.610091.x

Burton JP (2002) Effects of clearcut edges on trees in the Subboreal spruce zone of Northwest-Central British Columbia. Silva Fenn 36:329-352. https://doi.org/10.14214/sf.56

Cadenasso ML, Traynor MM, Pickett STA (1997) Functional location of forest edges: gradients of multiple physical factors. Can J For Res 27:774-782. https://doi.org/10. 1139/x97-013

Cadenasso ML, Pickett STA, Weathers KC, Bell SS, Benning TL, Carreiro MM, Dawson TE (2003a) An interdisciplinary and synthetic approach to ecological boundaries. Bioscience 53:717-722. https://doi.org/10.1641/00063568(2003)053[0717:AIASAT]2.0.CO;2

Cadenasso ML, Pickett STA, Weathers KC, Jones CG (2003b) A framework for a theory of ecological boundaries. Bioscience 53:750-758. https://doi.org/10.1641/00063568(2003)053[0750:AFFATO]2.0.CO;2

De Casenave JL, Pelotto JP, Protomastro J (1995) Edge-interior differences in vegetation structure and composition in a Chaco semi-arid forest, Argentina. Forest Ecol Manag 72:61-69

di Castri F, Hansen AJ (1992) The environment and development crises as determinants of landscape dynamics. In: Hansen AJ, Castri F (eds) Landscape boundaries: consequences for biotic diversity and ecological flows. Springer, New York, pp 3-18

Chen J, Franklin JF, Spies TA (1992) Vegetation responses to edge environments in old-growth Douglas-fir forests. Ecol Appl 2:387-396. https://doi.org/10.2307/1941873

Chen J, Franklin JF, Spies TA (1995) Growing-season microclimatic gradients from clearcut edges into old-growth Douglas-fir forests. Ecol Appl 5:74-86. https://doi.org/10. 2307/1942053

Chytrý M, Tichý L, Holt J, Botta-Dukát Z (2002) Determination of diagnostic species with statistical fidelity measures. J Veg Sci 13:79-90. https://doi.org/10.1111/j.1654-1103. 2002.tb02025.x

Dengler J, Janišová M, Török P, Wellstein C (2014) Biodiversity of Palaearctic grasslands: a synthesis. Agr Ecosyst Environ 182:1-14. https://doi.org/10.1016/j.agee.2013.12. 015

Devlaeminck R, Bossuyt B, Hermy M (2005) Inflow of seeds through the forest edge: evidence from seed bank and vegetation patterns. Plant Ecol 176:1-17. https://doi.org/ 10.1007/s11258-004-0008-2

Diekmann M (2003) Species indicator values as an important tool in applied plant ecology - a review. Basic Appl Ecol 4:493-506. https://doi.org/10.1078/1439-1791-00185

Dierschke H (1974) Saumgesellschaften im Vegetations- und Standortsgefälle an Waldrändern. Script Geobot 6:1-246

Dislich R, Mantovani W (2016) Vascular epiphyte assemblages in a Brazilian Atlantic Forest fragment: investigating the effect of host tree features. Plant Ecol 217:1-12. https:// doi.org/10.1007/s11258-015-0553-X

Dodonov P, Harper KA, Silva-Matos DM (2013) The role of edge contrast and forest structure in edge influence: vegetation and microclimate at edges in the Brazilian cerrado. Plant Ecol 214:1345-1359. https://doi.org/10.1007/ s11258-013-0256-0 
Dzwonko Z (2001) Assessment of light and soil conditions in ancient and recent woodlands by Ellenberg indicator values. J Appl Ecol 38:942-951. https://doi.org/10.1046/j. 1365-2664.2001.00649.x

Ellenberg H (1988) Vegetation ecology of central Europe, 4th edn. Cambridge University Press, Cambridge

Ellenberg H, Weber HE, Düll R, Wirth V, Werner W, Paulißen D (1992) Zeigerwerte von Pflanzen in Mitteleuropa. Scr Geobot 18:1-248

Erdős L, Gallé R, Bátori Z, Papp M, Körmöczi L (2011) Properties of shrubforest edges: a case study from South Hungary. Cent Eur J Biol 6:639-658. https://doi.org/10.2478/ s11535-011-0041-9

Erdős L, Gallé R, Körmöczi L, Bátori Z (2013) Species composition and diversity of natural forest edges: edge responses and local edge species. Community Ecol 14:48-58. https://doi.org/10.1556/ComEc.14.2013.1.6

Erdős L, Cs Tölgyesi, Horzse M, Tolnay D, Hurton Á, Schulcz N, Körmöczi L, Lengyel A, Bátori Z (2014) Habitat complexity of the Pannonian forest-steppe zone and its nature conservation implications. Ecol Complex 17:107-118. https://doi.org/10.1016/j.ecocom.2013.11. 004

Erdős L, Ambarlı D, Anenkhonov OA, Bátori Z, Cserhalmi D, Kiss M, Gy Kröel-Dulay, Liu H, Magnes M, Zs Molnár, Naqinezhad A, Semenishchenkov YA, Cs Tölgyesi, Török P (2018a) The edge of two worlds: a new review and synthesis on Eurasian forest-steppes. Appl Veg Sci 21:345-362. https://doi.org/10.1111/avsc.12382

Erdős L, Gy Kröel-Dulay, Bátori Z, Kovács B, Cs Németh, Kiss PJ, Cs Tölgyesi (2018b) Habitat heterogeneity as a key to high conservation value in forest-grassland mosaics. Biol Conserv 226:72-80. https://doi.org/10.1016/j.biocon. 2018.07.029

Euskirchen ES, Chen J, Bi R (2001) Effects of edges on plant communities in a managed landscape in northern Wisconsin. Forest Ecol Manag 148:93-108. https://doi.org/10. 1016/S0378-1127(00)00527-2

Fagan WF, Cantrell RS, Cosner C (1999) How habitat edges change species interactions. Am Nat 153:165-182. https:// doi.org/10.1086/303162

Forman RTT, Moore PN (1992) Theoretical foundations for understanding boundaries in landscape mosaics. In: Hansen AJ, Castri F (eds) Landscape boundaries: Consequences for biotic diversity and ecological flows. Springer, New York, pp 236-258

Fraver S (1994) Vegetation responses along edge-tointerior gradients in the mixed hardwood forests of the Roanoke River Basin, North Carolina. Conserv Biol 8:822-832. https://doi.org/10.1046/j.1523-1739.1994.08030822.x

Gehlhausen SM, Schwartz MW, Augspurger CK (2000) Vegetation and microclimatic edge effects in two mixed-mesophytic forest fragments. Plant Ecol 147:21-35. https://doi. org/10.1023/A:1009846507652

Haddad NM, Brudvig LA, Clobert J, Davies KF, Gonzalez A, Holt RD, Lovejoy TE, Sexton JO, Austin MP, Collins CD, Cook WM, Damschen EI, Ewers RM, Foster BL, Jenkins CN, King AJ, Laurance WF, Levey DJ, Margules CR, Melbourne BA, Nicholls AO, Orrock JL, Song D-X, Townshend JR (2015) Habitat fragmentation and its lasting impact on Earth's ecosystems. Sci Adv 1:e1500052. https://doi.org/10.1126/sciadv.1500052

Harper KA, MacDonald SE (2002) Structure and composition of edges next to regenerating clear-cuts in mixed-wood boreal forest. J Veg Sci 13:535-546. https://doi.org/10.1111/j. 1654-1103.2002.tb02080.x

Harper KA, MacDonald SE, Burton PJ, Chen J, Brosofske KD, Saunders SC, Euskirchen ES, Roberts D, Jaiteh MS, Esseen PA (2005) Edge influence on forest structure and composition in fragmented landscape. Conserv Biol 19:768-782. https://doi.org/10.1111/j.1523-1739.2005.00045.x

Harper KA, Lavallee AA, Dodonov P (2018) Patterns of shrub abundance and relationships with other plant types within the forest-tundra ecotone in northern Canada. Arctic Sci. https://doi.org/10.1139/as-2017-0028

Heithecker TD, Halpern CB (2007) Edge-related gradients in microclimate in forest aggregates following structural retention harvests in western Washington. Forest Ecol Manag 248:163-173. https://doi.org/10.1016/j.foreco. 2007.05.003

Hennenberg KJ, Goetze D, Kouamé L, Orthmann B, Porembski S (2005) Border and ecotone detection by vegetation composition along forest-savanna transects in Ivory Coast. J Veg Sci 16:301-310. https://doi.org/10.1111/j.16541103.2005.tb02368.x

Hill MO, Gauch HG (1980) Detrended Correspondence Analysis: an improved ordination technique. Vegetatio 42:47-58. https://doi.org/10.1007/978-94-009-9197-2_7

Honnay O, Verheyen K, Hermy M (2002) Permeability of ancient forest edges for weedy plant species invasion. Forest Ecol Manag 161:109-122. https://doi.org/10.1016/ S0378-1127(01)00490-X

Horvat I, Glavač V, Ellenberg H (1974) Vegetation Südosteuropas. Gustav Fischer, Stuttgart

Hufkens K, Scheunders P, Ceulemans R (2009) Ecotones in vegetation ecology: methodologies and definitions revisited. Ecol Res 24:977-986. https://doi.org/10.1007/ s11284-009-0584-7

Ibanez T, Hély C, Gaucherel C (2013) Sharp transitions in microclimatic conditions between savanna and forest in New Caledonia: insights into the vulnerability of forest edges to fire. Austral Ecol 38:680-687. https://doi.org/10. 1111/aec. 12015

Jakucs P (1972) Dynamische Verbindung der Wälder und Rasen. Akadémiai Kiadó, Budapest

Kahmen S, Poschlod P, Schreiber KF (2002) Conservation management of calcareous grasslands. Changes in plant species composition and response of functional traits during 25 years. Biol Conserv 104:319-328. https://doi.org/ 10.1016/S0006-3207(01)00197-5

Kark S, van Rensburg BJ (2006) Ecotones: marginal or central areas of transition? Isr J Ecol Evol 52:29-53. https://doi. org/10.1560/IJEE.52.1.29

Kent M, Gill WJ, Weaver RE, Armitage RP (1997) Landscape and plant community boundaries in biogeography. Prog Phys Geog 21:315-353. https://doi.org/10.1177/ 030913339702100301

Kolasa J (2014) Ecological boundaries: a derivative of ecological entities. Web Ecol 14:27-37. https://doi.org/10.5194/ we-14-27-2014 
Lloyd KM, McQueen AAM, Lee BJ, Wilson RCB, Walker S, Wilson JB (2000) Evidence on ecotone concepts from switch, environmental and anthropogenic ecotones. J Veg Sci 11:903-910. https://doi.org/10.2307/3236560

Łuczaj Ł, Sadowska B (1997) Edge effect in different groups of organisms: vascular plant, bryophyte and fungi species richness across a forest-grassland border. Folia Geobot Phytotax 32:343-353. https://doi.org/10.1007/ BF02821940

Magyari EK, Chapman JC, Passmore DG, Allen JRM, Huntley JP, Huntley B (2010) Holocene persistence of wooded steppe in the Great Hungarian Plain. J Biogeogr 37:915-935. https://doi.org/10.1111/j.1365-2699.2009. 02261.x

Mangiafico S (2018) rcompanion: functions to support extension education program evaluation. $\mathrm{R}$ package version 1.13.2. https://CRAN.R-project.org/package=rcompanion. Accessed 15 July 2018.

Mayer B, Vrbek B (1995) Structure of soil cover on dolomites of Samobor and Zumberak Hills. Acta Bot Croat 54:141-149

Merriam G, Wegner J (1992) Local extinctions, habitat fragmentation, and ecotones. In: Hansen AJ, Castri F (eds) Landscape boundaries: consequences for biotic diversity and ecological flows. Springer, New York, pp 150-169

Moog D, Poschlod P, Kahmen S, Schreiber KF (2002) Comparison of species composition between different grassland management treatments after 25 years. Appl Veg Sci 5:99-106. https://doi.org/10.1111/j.1654-109X.2002. tb00539.x

Müller SC, Overbeck GE, Pfadenhauer J, Pillar VD (2012) Woody species patterns at forest-grassland boundaries in southern Brazil. Flora 207:586-598. https://doi.org/10. 1016/j.flora.2012.06.012

Molnár Z (1998) Interpreting present vegetation features by landscape historical data: an example from a woodlandgrassland mosaic landscape (Nagykőrös Wood, Kiskunság, Hungary). In: Kirby KJ, Watkins C (eds) The ecological history of European forests. CAB International, Wallingford, pp 241-263

Naiman RJ, Décamps H, Pastor J, Johnston CA (1988) The potential importance of boundaries to fluvial ecosystems. J N Am Benthol Soc 7:289-306. https://doi.org/10.2307/ 1467295

Odum EP (1971) Fundamentals of ecology, 3rd edn. WB Saunders, Philadelphia

Oksanen J, Blanchet FG, Friendly M, Kindt R, Legendre P, McGlinn D, Minchin PR, O'Hara RB, Simpson GL, Solymos P, Stevens MHH, Szoecs E, Wagner H (2018) vegan: community Ecology Package. $\mathrm{R}$ package version 2.5-1. https://CRAN.R-project.org/package=vegan. Accessed 15 July 2018

Öllerer K (2014) The ground vegetation management of woodpastures in Romania - insights in the past for conservation management in the future. Appl Ecol Environ Res 12:549-562. https://doi.org/10.15666/aeer/1202_549562

Ostermann OP (1998) The need for management of nature conservation sites designated under Natura 2000. J Appl Ecol 35:968-973. https://doi.org/10.1111/j.1365-2664. 1998.tb00016.x

Palo A, Ivask M, Liira J (2013) Biodiversity composition reflects the history of ancient semi-natural woodland and forest habitats-Compilation of an indicator complex for restoration practice. Ecol Indic 34:336-344. https://doi. org/10.1016/j.ecolind.2013.05.020

Peters DPC, Gosz JR, Pockman WT, Small EE, Parmenter RR, Collins SL, Muldavin E (2006) Integrating patch and boundary dynamics to understand and predict biotic transitions at multiple scales. Landscape Ecol 21:19-33. https://doi.org/10.1007/s10980-005-1063-3

Pianka ER (1983) Evolutionary ecology, 3rd edn. Harper and Row, New York

Pignatti S (2005) Valori di bioindicazione delle piante vascolari della flora d'Italia. Braun-Blanquetia 39:1-97

Pohlert T (2014) The Pairwise Multiple Comparison of Mean Ranks Package (PMCMR). R package, URL https:// CRAN.R-project.org/package=PMCMR. Accessed 2 November 2018

R Core Team (2018) R: a language and environment for statistical computing. R Foundation for Statistical Computing, Vienna, Austria. https://www.R-project.org/. Accessed 15 July 2018

Ries L, Fletcher RJJr, Battin J, Sisk TD, (2004) Ecological responses to habitat edges: mechanisms, models, and variability explained. Annu Rev Ecol Evol Syst 35:491-522. https://doi.org/10.1146/annurev.ecolsys.35. 112202.130148

Ries L, Murphy SM, Wimp GM, Fletcher RJJr, (2017) Closing Persistent Gaps in Knowledge About Edge Ecology. Curr Landscape Ecol Rep 2:30-41. https://doi.org/10.1007/ s40823-017-0022-4

Risser PG (1995) The status of the science examining ecotones. Bioscience 45:318-325. https://doi.org/10.2307/1312492

Römermann C, Bernhardt-Römermann M, Kleyer M, Poschlod P (2009) Substitutes for grazing in semi-natural grasslands-do mowing or mulching represent valuable alternatives to maintain vegetation structure? J Veg Sci 20:1086-1098

Santos AMM, Santos BA (2008) Are the vegetation structure and composition of the shrubby Caatinga free from edge influence? Acta Bot Bras 22:1077-1084. https://doi.org/10. 1590/S0102-33062008000400018

Schaffers AP, Sýkora KV (2000) Reliability of Ellenberg indicator values for moisture, nitrogen and soil reaction: a comparison with field measurements. J Veg Sci 11:225-244. https://doi.org/10.2307/3236802

Sjörs H (1986) On the gradient from near-natural to man-made. Transactions of the Botanical Society of Edinburgh 45:77-84. https://doi.org/10.1080/03746608608684996

ter Braak CFJ, Gremmen NJM (1987) Ecological amplitudes of plant species and the internal consistency of Ellenberg's indicator values for moisture. Vegetatio 69:79-87. https:// doi.org/10.1007/978-94-009-4061-1_8

Tichý L (2002) JUICE, software for vegetation classification. J Veg Sci 13:451-453. https://doi.org/10.1111/j.16541103.2002.tb02069.x

Tichý L, Chytrý M (2006) Statistical determination of diagnostic species for site groups of unequal size. J Veg Sci 17:809-818. https://doi.org/10.1111/j.1654-1103.2006. tb02504.X

Tokuoka Y, Ohigashi K, Nakagoshi N (2011) Limitations on tree seedling establishment across ecotones between abandoned fields and adjacent broad-leaved forests in 
eastern Japan. Plant Ecol 212:923-944. https://doi.org/10. 1007/s11258-010-9868-9

Tölgyesi C, Bátori Z, Erdős L (2014) Using statistical tests on relative ecological indicators to compare vegetation units-different approaches and weighting methods. Ecol Indic 36:441-446. https://doi.org/10.1016/j.ecolind.2013. 09.002

Tölgyesi C, Bátori Z, Gallé R, Urák I, Hartel T (2018) Shrub encroachment under the trees diversifies the herb layer in a Romanian silvopastoral system. Rangeland Ecol Manag 71:571-578. https://doi.org/10.1016/j.rama.2017.09.004

Trinajstić I (1995) Samoborsko Gorje, a refuge of various floral elements between the Alps and the Dinaric Mountains. Acta Bot Croat 54:47-62

Trinajstić I (2008) Biljne zajednice Republike Hrvatske. Akademija Šumarskih Znanosti, Zagreb

van der Maarel E (1990) Ecotones and ecoclines are different. J Veg Sci 1:135-138. https://doi.org/10.2307/3236065

Valkó O, Venn S, Żmihorski M, Biurrun I, Labadessa R, Loos J (2018) The challenge of abandonment for the sustainable management of Palaearctic natural and semi-natural grasslands. Hacquetia 17:5-16. https://doi.org/10.1515/ hacq-2017-0018

Vukelić J (2012) Šumska vegetacija Hrvatske. University of Zagreb, Zagreb
Walker S, Wilson JB, Steel JB, Rapson GL, Smith B, King WM, Cottam YH (2003) Properties of ecotones: evidence from five ecotones objectively determined from a coastal vegetation gradient. J Veg Sci 14:579-590. https://doi.org/10. 1111/j.1654-1103.2003.tb02185.x

Wallis De Vries MF, Poschlod P, Willems JH (2002) Challenges for the conservation of calcareous grasslands in northwestern Europe: integrating the requirements of flora and fauna. Biol Conserv 104:265-273. https://doi.org/10.1016/ S0006-3207(01)00191-4

Wicklein HF, Christopher D, Carter ME, Smith BH (2012) Edge effects on sapling characteristics and microclimate in a small temperate deciduous forest fragment. Nat Area J 32:110-116. https://doi.org/10.3375/043.032.0113

Yarrow MM, Marín VH (2007) Toward conceptual cohesiveness: a historical analysis of the theory and utility of ecological boundaries and transition zones. Ecosystems 10:462-476. https://doi.org/10.1007/s10021-007-9036-9

Publisher's Note Springer Nature remains neutral with regard to jurisdictional claims in published maps andinstitutional affiliations. 